\title{
Modern Warfare and Its Evolving Weapons - Assumptions and Inherent Contradictions
}

\author{
Richard Rousseau
}

Khazar University, Baku, Azerbaijan

\section{The Way Things Were}

In the 20th century the world's defense communities often produced spectacularly inaccurate forecasting and intelligence reports. Outdated ideas were clung to as dogma and new developments not embraced with disturbing regularity.

One hundred years ago Great Britain stood tall as the world's superpower and exuded hubris, unaware that much of the oncoming century would offer it a bitter diet of nemesis and decline, a future many British politicians tried to ignore, though the signs were long visible. For example, in 1906 the Royal Navy introduced submarines into its arsenal and remained content with this innovation, thinking that it gave it a big edge over its enemies. ${ }^{1}$ Eight years later, in September 1914, however, the German U9 submarine torpedoed and sank three British cruisers in the North Sea, killing 1,459 officers and crew. ${ }^{2}$ Nevertheless, the submarine has continued to evolve and remains a vital part of any major nation's defense capability, a trend likely to continue. The importance of marine warfare increased during both World Wars ${ }^{3}$ and throughout the Cold War, and, despite some drawbacks since 1991, this tendency in the UK to depend on the navy as a major strategic instrument will remain for decades to come.

Aircraft are also an essential part of any military complement. As early as October 1908 S. F. Cody, an American, made the first military flight in Britain, covering 1,390 feet in British Army Aircraft No. 1. The Italians first used a heavier-than-air aircraft - in a combat situation - to drop a bomb on Turkish forces on November 1, 1911. Once again, within a short time military combat aircraft evolved to revolutionize twenty-first century warfare, operating from both land and sea. Some now opine that the present Joint Strike Jet Fighters may be the last generation of manned supersonic combat aircraft. Maybe, but this "last generation" may endure for more than 50 years (and the much upgraded B-52 bombers may even last a century as a front line plane), since unmanned aircraft (drones) have hardly begun to realize their full capability. In this sense, there appears to be little, if any, 
indication of a significant swing taking place from air attack towards air defense capabilities. ${ }^{4}$

The first Dreadnought class battleship entered service in the British Royal Navy in December 1906, which thus completed the transformation of its fleet from one based around the wooden battleships of Nelson of Trafalgar's time to one based around steel. ${ }^{5}$ Forty years later battleships had already become outdated, although they lingered on as a means of conducting the bombardment of shore sites for some decades, only to be gradually replaced with airplanes and submarines. These new weapons took over the role that such heavy ships had been designed for, putting the purpose of retaining such ships in question. ${ }^{6}$

The tank, the dominant vehicle of 20st century land warfare, emerged only a decade later, in 1916, at the battle of Flers-Courcelette near the Somme. Today it is still powerful, but the future of warfare may depend on having the right balance of armor plating, lethality, mobility and air transportation capability. ${ }^{7}$ Like submarines and aircraft, tanks will have to become more adaptable in the 21st century if they are to maintain a significant position in the arsenals of the world's defense forces.

Some items of military hardware, though, have stood the test of time better. The machine gun was perhaps the dominant small artillery weapon in the period prior to World War I. The Gatling gun was first used by the U.S. Army as early as 1864, and adopted by the British in 1880 . Various models and designs of machine guns are still widely used today, and seem likely to continue to be the hand weapons of choice as warfare evolves. Like the adaptable Kalashnikov AK-47, they are now universal close quarters armaments of choice, including for criminals. ${ }^{8}$

Today we have the C4ISR (the U.S. term for Command, Control, Communications, Computers, Intelligence, Surveillance, and Reconnaissance), ${ }^{9}$ derived from and enabled by the digital computer and the chip age. However, in 1906 both the computer and chip technology were far into the future. ${ }^{10}$ Command and control functions certainly existed, but their scope was restricted by the technology and human understanding of the time. ${ }^{11}$ Now the computing power of chips is doubling every 18 to 24 months, and the only limitation to what can be achieved is probably human imagination. ${ }^{12}$ The evolution of this sphere of modern weaponry is of crucial importance to the nature of warfare in the 21 st century.

One hundred years ago space travel and "star wars" technology were things out of science fiction, yet just over 50 years later the first Sputnik orbiter was sent into 
space. Today, the main purpose of space in warfare is to station sensors and global communications systems. Missiles fly through space to hit their targets. The next step to acquiring the capabilities for conducting a war in space will be a small one. It may be that the use of space will be to the 21 st century what the use of the air was to the 20th. ${ }^{13}$

In 1906 nuclear science was in its infancy. Yet, through European research and American development, a nuclear bomb was dropped on Hiroshima at the end of World War II, less than 40 years later. Since then, the principal purpose of having nuclear weapons has been to use them as a deterrent, since actually setting them on an enemy would assure mutual destruction. ${ }^{14}$ This standoff, though, may not continue, and the main question concerning nuclear weapons in the future may not be their enormous capabilities but who should have access to them, how they will be activated and under what circumstances.

Ironically, the first uses of chemical and biological warfare are mired in history, and there are international conventions limiting their use. ${ }^{15}$ But these conventions are weak, and chemical and biological weapons will continue to be used when an advantage in doing so is perceived by the owner. Again, when and how they are to be used are the key questions.

The will to fight, to win, and to go on fighting was strong in 1906. The antagonists of World War I had been squaring up to each other long before then. The idea of establishing an international collective security organization (the future League of Nations), which was already floating in the first decade of the 20th century, was pushed aside as unnecessary by the great powers even before World War I. The United Nations and NATO were only created after a second monumentally destructive world war. ${ }^{16}$

The fighting resilience demonstrated between 1914 and 1918 was phenomenal and was seen again between 1939 and 1945. In today's asymmetrical security environment, however, strategic resilience is more problematic because asymmetry can be reversed. The will of a nation is to a great extent driven by the media. ${ }^{17}$ The media tells a people at war what they want to see or hear, and what other people and nations want them to see and hear. The media's technological sophistication has made possible instant, globalized and intrusive coverage of daily events. The media, in its many forms of information and intelligence, is increasingly influencing decision-making processes.

One more stable factor in this mix is the function and role of different groups of people. The 20th century saw a gradual strengthening of the value military 
organizations put on service persons, and increasingly servicewomen, in developed countries. Now women, in highly industrial countries, are central to any military operation.

However, the general conclusion that can be drawn from the 20th century military experience is that, overall, it is difficult to see why the military should be better at long-term forecasting in 2012 than it was in 1906.

\section{The Way the Military Is Going}

If there is a link between the world of 1906 and that of 2012, it is diffuse and weak, more the product of chaos theory than a proverbial golden thread. So far in the 21 st century the world has been shocked and surprised by international events. There is little convincing evidence that this tendency to be shocked and surprised will not continue into the indefinite future.

The terrorist acts of 9/11 gave a vicious and profound wake up call to the United States; they changed much of the global security environment. Yet, particularly in retrospect, a steady flow of clues and precursors had made this atrocity predictable. 9/11 was not technology-driven, as the "weapons of mass destruction" used were passenger planes - commercial vessels, but full of fuel and people - and the triggering weapons were Stanley box cutters. The terrorists had an effective C2 system (command and control system), but the hardware for this was commercially available.

Although the 9/11 events also blasted a country like the United Kingdom, removed from the United States by an ocean, occurrences there in the previous 18 months, including a drivers' strike over fuel, widespread floods and a foot and mouth epidemic, had already persuaded the British government that the country's infrastructure was disjointed and fragile. Having espoused an "expeditionary strategy" since at least 1998, Britain assumed that any threats to the country would come from abroad. The bomb attacks in London of 7 July 2005, in which the terrorists were "home grown," blurred the distinction between internal and external threats, and hence responses.

The U.S.-led military campaign in Iraq, which reached the centre of Baghdad so swiftly in March/April of 2003, demonstrated the success of the transformation of the U.S. army into a military force built on speed, precision, firepower and knowledge. The combat capability of the force was barely tested, as Saddam's 
forces melted before the American advance, but the appearance of a rag-bag of Fedayeen, in the midst of this grand advance, clearly discomforted U.S. land forces. Moreover, the absence of appropriate planning for what would be done after Baghdad had been "liberated" resulted in the military coalition losing the political initiative on the ground, and by the same token the goodwill of the local population in the process. ${ }^{18}$ The turbulent, shapeless and deadly insurgency that filled in the void on the Iraqi side may be a portent of the sort of irregular warfare countries will have to deal with in the future.

In today's world, the military focuses predominantly on land based irregular warfare, even if attacks can also come from the air and sea. However, despite the continued threat these pose, international air and sea trade transport continues, and is even increasing. ${ }^{19}$ The bulk of trade is moved by sea, in containers, and as trade continues to expand to developing economies and developed countries attempt to more effectively limit pollution, particularly carbon emissions, the proportion of trade moved by sea will certainly not decrease. In fact it seems likely that sea transported trade (essentially by containers) will increase even further. ${ }^{20}$ If sea transported trade increases, and the merchandise is considered valuable by criminal organizations and nations that are in conflict with the destinations of these ships, they will become more and more tempting targets. If such attacks become common, they will be fiercely resisted, initially at various choke points and then further out in the open oceans. Submarines will have a vital role to play in this expanding security issue and they will be concealed in the deep oceans. ${ }^{21}$

The future importance of intelligence was demonstrated by the military campaign in Iraq. As a result of intense and extended technical and human intelligence gathering, the United States was able to make a preemptive strike, 24 hours before the invasion of Iraq, on a bunker at Dora Farm, southeast of Baghdad, in which Saddam and his sons were supposed to be hiding. The bombs and missiles hit the farm, but it turned out not to be a bunker and Saddam and his sons were not there. ${ }^{22}$ Here intelligence failed miserably, as it did so many times in Iraq. The lesson of this blunder should resound through the rest of this century: Substandard intelligence mixed with wishful thinking and political expediency will beget failure.

\section{Dynamics of Change}

Change in the defense and security fields is bound to occur because, around the world, countries' military and criminal organizations always want to improve their capability to do what they want to do. There are concurrent political and industrial 
advantages to doing so, but undertaking changes generate huge costs. Sometimes an opportunity arises to make a leap forward through a specific technological advance or accumulated evolutionary steps. Sometimes different tools offer nations the opportunity to conduct the same or different tasks in different ways. Change is disruptive, but widely accepted as being both inevitable and essential. Change is to the defense planner what the ice-bath is to the well-honed athlete. It is not, however, a process which can be undertaken without constraints, and the first constraint is financial.

Research can be funded, but not all the best minds can be rallied at the same time to do the research. ${ }^{23}$ It follows that further development, production and support are primarily dependent upon funding sources. It also means that over a period of time, and assuming great fortitude and will power within a nation, a sustained rise in economic strength should lead to that nation gaining even greater defense and security capabilities. With that in mind, it can be predicted that the United States will continue to be the preeminent military power and that the capabilities of China and India may rise to challenge those of the United States, at least in American eyes. $^{24}$ Meanwhile, Europe may collectively have the economic strength to compete with the U.S. but lack the concerted will to use it to challenge current and emerging great powers. ${ }^{25}$ For its part, Russia may battle with Europe for resources and control of Eastern Europe and the Caucasus, with the longer term aim of reestablishing itself as a military superpower. ${ }^{26}$

Powerful countries should not count on being liked and admired. They are more likely to be opposed and annoyed asymmetrically. The success or failure of asymmetric action will depend on a number of factors. Key to this is whether asymmetric $\mathrm{C} 2$ can flourish when used imaginatively and when unconstrained by national and international laws, morality and electoral accountability, or whether it will be disrupted by the capabilities of stronger powers, which will be able to intercept, analyze and react to electronic emissions. ${ }^{27}$ Linked to this issue is the question of whether an ever greater proportion of high-capability IT systems will be available commercially. Another factor to consider is that small and agile organizations may be able to operate by making minimal, hidden and secure emissions. ${ }^{28}$ These issues may become critical to the future of insurgencies and terrorism during the 21 st century.

Also affecting the future of insurgents and terrorists will be the availability of finance. ${ }^{29}$ This is a critical factor, but the amounts of money required do not have to be enormous. On the other hand, huge funds will be needed if terrorists/ insurgents decide they must use chemical, biological or nuclear agents. ${ }^{30}$ For sure, 
terrorists and insurgents will act, to a greater or lesser extent, ruthlessly. The probability seems high that in due course chemical and biological weapons (CBW weapons) will be put to use by this type of enemy. That, however, may not come without risk to the attackers, for it will not only expose them, before and after they spread chemical or biological substances or launch a nuclear missile, to countermeasures, but also possibly alienate their strategic base of support.

This aspect of military defense in the 21 st century has to be linked to the most important factor in warfare: maintaining the will to win. The population of a country and its government may go soft, becoming reluctant even to allow their military to continue with dangerous and morally debatable military operations, especially in faraway lands. However, faced with threats to vital national interests, energy security or even national survival, democracies may get tougher, shifting the delicate balance between security and human rights imperatives. Such a balance presents a challenge to all governments, which need to educate their populations about how not to be terrorized by terrorists. As most statistics show, deaths on the roads kill far more people than terrorists, and the outcome of a flu pandemic would be worse than the release of a chemical substance in an urban area. Insurgents and terrorists usually have an uncomplicated approach to warfare, some seeing death as desirable and glorious. At the core, insurgents and terrorist groups may not break up into smaller groups, but their supporters and sympathizers may drift away. ${ }^{31}$

Many governments have conflict resolution programs and a mandate to reduce and remove the root causes of opposition, revolt, insurgencies or terrorism. The difficulty is that long-term and soft security measures often clash with short-term and hard security ones, to the advantage of neither. Creating a balance between hard, soft, long and short-term security measures is, for states, critical to obtaining favorable outcomes.

Change, especially when it involves major material disruption and high costs, is likely to be resisted. But there are also risks to opposing change. The changes made in the U.S. Army enabled the United States to successfully invade Iraq in 2003. On the other hand, the U.S. seemed much less successful in making needed changes after the initial objective, getting to central Baghdad, had been achieved. There will usually be less perceived risk in doing more of what one has already been doing for a certain period of time. This is especially the case for countries which are hardpressed to meet current financial commitments. Expensive change with added risk will appear unattractive, even if the potential gain is substantial. Hence, countries will tend to prefer lower-cost, lower-risk and lower-gain options. This may well be a false calculation, not least because any subsequent requirement will force a 
country to catch up in a hurry, elevating the risk of making fatal mistakes. In any case, change across nations has proven generally inefficient again and again.

A policy of no change or minimum change is also likely to be self-defeating and increase costs in the long term. A quick survey of the last century demonstrates that its enduring certainties about warfare were almost all proven wrong. ${ }^{32}$ To invest in a single option - or a few options - that diverge wildly from contemporary practices may be heroic, but not necessarily helpful. A systematic approach to anticipating change requires an analysis of risk against gain, and graded options for investment.

The rate of equipment capability improvement will vary greatly. Some platforms will become venerable, some will go into oblivion. The last B-52 was withdrawn from front line service almost 100 years after first entering into service, but the capability of the B-52 had been upgraded several times during the aircraft's life and it had taken on different tasks. Within the same platform, weapons systems can very rapidly be enhanced. In seeking new capabilities, the long cycle times of major platforms have to be able to accommodate the very short timescales of system updates. Successful changes in equipment capability are also dependent on the quality and adaptability of the people manning the equipment, and this in turn depends mainly on education, training and the quality of the trainers. ${ }^{33}$ Finally, change depends on the intentions and decisions of political leaders (in a democracy, civil leaders). President Truman's decision to drop an atomic bomb on Hiroshima, however highly controversial and morally debatable, induced a flood of change, as did President Bush's decision to invade Iraq in March 2003. Both were discretionary decisions.

Since the end of World War I the search for effective supranational security has continued, but not unabated. After World War II the emergence of a "Cold War" between the Western and the Communist geopolitical blocs justified the creation of NATO in 1949, but the collapse of the Soviet Union saw the Alliance struggling to transform itself and find another raison d'être. Perhaps it has done so in theory and on the surface, but its internal functioning and practices remain in doubt. ${ }^{34}$ Today's security environment has not proved propitious for either NATO or the United Nations. ${ }^{35}$ Challenges lie ahead for both, and neither seems as agile, determined and effective as they should or could be. In Great Britain there is a famous saying: "fine words butter no parsnips" (meaning that words alone are useless). International institutions are awash with fine words, but the parsnips remain unbuttered. They could change for the better, but things may have to get worse before the international community is forced into taking resolute and enduring action. 
When democracies wage war they now demand more from their people, not in terms of sacrifice, for the casualties of the two world wars were far higher than those which have occurred so far in the 21 st century, but in terms of their servicemen and women since they are becoming increasingly valuable assets, requiring consistently higher skill levels, while retaining the traditional military virtues. ${ }^{36}$ As these individuals become better trained and more capable - and at the same time more costly - their numbers will tend to fall. Yet military personnel are becoming indivisible, and, no matter how well networked and equipped they are, they will still be needed in quite large numbers in each individual nation. This poses cost-effectiveness and demographic dilemmas.

Then there are the "unknowns." The genuine "unknowns" are beyond rational and fact-based forecasting. But there are "unknowns" that can be more easily included in strategic calculation, and through imaginative extrapolation from what is anticipated one can look for and find needles in haystacks and bits of gold on beaches. Many unknowns have a low probability of occurring, but coping well with them can produce a very high gain for military planners. Addressing these unknowns should be pursued against the odds.

\section{Snapshots of 21st Century Warfare}

There will be contrasts between 21st century warfare and the forms we have previously witnessed. ${ }^{37}$ For example, highly developed societies will attempt to "engage the enemy more closely" (Horatio Nelson's famous order from Trafalgar) from further away. An example of this may be the use of the Unmanned Aerial Vehicle (UAV), which as a system uses as many people as manned aircraft but is less risky, cheaper and more effective. While UAVs may be flown, and therefore attacks can be carried out with precision by pilots located thousands of kilometers from these aircrafts, "boots on the ground" will still be needed, and still in large numbers. But the "boots" will need to be networked, skilled and supported.

Networks will be key enablers. The capability growth of C4ISR will continue to be phenomenal. But so will the key challenge of providing a comprehensive, global and detailed picture of the world's "hot spots." Providing networks for all seasons and all people is not yet within reach. Furthermore, networks can be frustrated, and to a greater or lesser extent countered. ${ }^{38}$ Forward leaps in technological development will become available to most countries, thereby reducing any of the decisive advantages gained by one or some states. Nevertheless, if the power of 
computers continues to rise almost exponentially during the next decades, the advances made will not only be huge but also surely unpredictable.

Artificial intelligence, nanotechnology and biological computation are among the most important developing technologies and are bound to change the face of armed conflicts. The need for accurate, timely and appropriate intelligence will grow. Failures in intelligence are unlikely to be eliminated and could have increasingly severe and global effects, because intelligence systems will be far-reaching and ostensibly capable of monitoring almost all villages on the planet. ${ }^{39}$

The multiplicity of actors involved in complex military operations and their varied contributions, requirements and mindsets represent huge challenges for the development of C4ISR. For many, even the use of the words "command and control" is anathema. The journey to improvements in C4ISR is expected to be long, complex and, in many instances, characterized by many countercultural developments. ${ }^{40}$

Asymmetric opponents, whether insurgents or terrorists, will proliferate, and under loose franchises even cooperate, at least for some decades. The use of military capability may not be proportional to the enemy fought against in the case of asymmetric conflicts. ${ }^{41}$ The virtual dimension of military operations in fighting an enemy ready to employ asymmetrical means will become dominant and the national will may be increasingly targeted by these fighters. The most secretive and loosely structured terrorist organizations will eventually be drawn into a media war. This may initially be of their choosing, but may open up vulnerabilities in their virtual armor.

Terrorism will come and go cyclically, with atrocity levels ratcheting up. Islamic extremism will peak in the next thirty years and then fade, as negotiations are progressively accepted by all parties. Also, during the same period more and more powerful weapons of mass destruction (WMD) are likely to be used, alongside biological, chemical and nuclear agents. In the long run, though, states' and international organizations' capability to prevent or preempt the use of these supremely deadly weapons looks problematic. During next thirty years the ability of the West to weaken support for extremists both within and outside their communities will prove the decisive factor. ${ }^{42}$

There will be a drift away from unrestricted conflicts, but wars in support of vital interests and for national survival will be harshly contested. ${ }^{43}$ Wars will be mostly fought for the same old historical reasons: resources, prejudices, pride, humanitarian imperatives, perceived morality and self-defense. ${ }^{44}$ 
Even the United States will increasingly come to terms with the need for multinational military and security organizations, but many nations will feel disinclined to bear their fair share of this burden. ${ }^{45}$ They will not take the necessary steps to make collective security effective. Permanent multinational security institutions are unlikely to develop conflict prevention, conflict resolution, peacekeeping and reconstruction strategies commensurate with their military and intelligence capabilities. "Coalitions of the willing" are likely to be favored, with some states developing deeper and more enduring interstate relations than others. Interoperability will grow between some partners, based on their self-interest and hard work, but also on cultural, technical, doctrinal, logistic and training factors. Interoperabilities of the mind will be difficult to develop. ${ }^{47}$

What one might cruelly call the "Africa syndrome" will not go away. This term refers to phenomena such as localized and regional genocide, frequent crimes against humanity or war crimes, using primitive and/or outdated weapons which are often unknown to most other parts of the world. ${ }^{48}$ These phenomena are not confined to the African continent, nor will they be in the future. But some of the most terrible recent cases have occurred there. Strangely, the developed world seems to be more often than not myopic about gestating horrendous conflicts on the "Dark Continent" and is blindsided by them more often than not. International institutions should not be expected to succeed in preventing all the cataclysms hitting Africa, although the need for them to do so will certainly rise.

Due to the increasing virtual dimension of military operations and the availability of global information, traditional military operations will increasingly be seen to be but one of many strands of what is sometimes called the "comprehensive approach." There may be two problems with this approach: First, the military contribution will tend to be dominant in the earlier stages of a campaign and then fade as the campaign evolves; second, the military will still tend to be the most appropriate structured institutions to organize and coordinate the overall effort. Such an arrangement may not be popular with certain national and international partners. $^{49}$

Maintaining the determination to win and survive will remain a crucial factor throughout the 21 st century. Sometimes, however, it will be almost totally submerged by the intensity of the technological and information-based environment. Hence, winning may become an unclear concept, but subverting or modifying the will of the enemy, in its various forms, will remain central to any approach to modern day warfare. 
Sadly, in the 21 st century we cannot rule out the possibility of massive and unconstrained conventional wars being fought between military superpowers. ${ }^{50}$ Such wars are on the horizon, as nuclear proliferation extends to currently non nuclear countries, and may include nuclear exchanges causing colossal human casualties and the creation of contaminated wastelands. Such a war could be a third world military conflict. This seems unlikely to happen in the next 20 years, but the century has eighty- eight more years to run.

Armed forces personnel will become harder to attract in the right numbers and with the right qualities and skills. Nevertheless, the gradually diminishing numbers of raw recruits will be offset by their increasing skill levels and refined qualities. Maintaining this better quality of human resources will remain critical to the prevention and resolution of conflicts.

The forecasters of 1906, given full knowledge of what is commonplace in 2012, would be staggered at the differences with their own day and the rapid changes which have taken place in warfare. Given that the rate of change today is accelerating and will probably continue to do so, we should accept that we lack the vision and the metrics to describe accurately what warfare will be like towards the end of this century. There will be monsters and there will be unknowns, some of which we are only starting to fully understand. But we should be alert for unknown unknowns and shocks, for they will certainly occur.

\section{References and Notes}

1. See Barry Posen, "Command of the Commons: The Military Foundation of U.S. Hegemony," International Security, Vol. 28, No. 1 (Summer 2003), pp. 5-46; Robert J. Lieber, The American Era: Power and Strategy for the 21st Century (Cambridge: Cambridge University Press, 2005), p. 35.

2. The Holland 1 submarine entered into service in the British Royal Navy in 1901. Sir Archibald Hurd said of the submarine in 1902 that, "The submarine is not an honest weapon. It suggests the foot pad, the garrotte, and the treacherous knife dug in an opponent's back when he is off guard."

3. See Morton Kaplan, System and Process in International Politics (New York: Wiley, 1957).

4. See Robert O.Work, "Winning the Race: A Naval Fleet Platform Architecture for Enduring Maritime Supremacy" (Washington, D.C.: Center for Strategic and Budgetary Assessments, 2005), p. 20-31.

5. Richard Haass, "What Follows American Dominion?" Financial Times, April 15, 2008.

6. See Paul Kennedy, The Rise and Fall of the Great Powers (New York: Random House, 1987).

7. Idem. 
8. See Mary L. Dudziak, War Time: An Idea, Its History, Its Consequences Oxford University Press, USA.

9. C4ISR is Command, Control, Communications, Computers, Intelligence, Surveillance, and Reconnaissance. Sometimes it is written as C4ISTAR, with the extra TA being Target Acquisition. C4ISR is enabled by networks, and hence provides network-enabled capability (NEC) or network-centric warfare (NCW).

10. Strategically, sea power was always the great enabler for British land power. The jibe that the British Army was a projectile fired by the Navy had a point. Famously, A. T. Mahan (Rear Admiral of the U.S. Navy) wrote of the British Royal Navy that, "Those far-distant, storm-beaten ships, upon which the Grand Army never looked, stood between it and the domination of the world." Arguably, the Battle of Waterloo was won not on the playing fields of Eton, as Montalembert suggested, but in the Atlantic off Cape Trafalgar.

11. The effectiveness of $\mathrm{C} 2$ depends on technology, but not absolutely. C2 of limited scope can be achieved with basic technology. Nelson's subordinate commanders, his "band of brothers," knew what was in his mind, and therefore needed only a few flag signals to implement his battle plan. At the Battle of Jutland in 1915 Jellicoe's C2 was obscured literally and figuratively by smoke. The calcification of British naval C2 between Trafalgar and Jutland is well described by Andrew Gordon in his book The Rules of the Game.

12. This logarithmic expansion is usually expressed in terms of the so-called Moore's Law. It has many formulations, but one of the more common is that the numbers of transistors on integrated circuits (a rough measure of computer processing power) doubles every 24 months. Moore made his original observation in 1965, expecting it to remain true for at least 10 years; it is still holding good today. It has been said that if Moore's Law was applied in the airline industry, a flight from New York to Paris, which in 1978 cost $\$ 900$ and took 7 hours, would now cost about $\$ 0.01$ and take less than one second.

13. See Stockholm International Peace Research Institute, SIPRI Yearbook 2010: Armaments, Disarmament, and International Security (Oxford: Oxford University Press, 2011), pp. 157-188.

14. Keir A. Lieber and Daryl G. Press, "The End of MAD? The Nuclear Dimension of U.S. Primacy,” International Security, Vol. 30, No. 4 (Spring 2006), pp. 7-44.

15. Mats Berdal, "The UN Security Council: Ineffective but indispensable." Survival, Vol. 45, No. 2, 2003, pp. 7-30.

16. See Rodney Bruce Hall, "Moral authority as a power resource." International Organization, Vol. 51, No. 4, 1997, p. 591-622.

17. See Bethany Encina and Nils Petter Gleditch, "Monitoring Trends in Global Combat: A New Dataset of Battle Deaths," European Journal of Population, Vol. 21, Nos. 2/3 (June 2005), pp. 145-166. Bruce Russett, "Peace in the Twenty-First Century?" Current History, January 2010, p. 9.

18. See Benjamin Miller, "Explaining Changes in U.S. Grand Strategy: 9/11, the Rise of Offensive Liberalism, and the War in Iraq," Security Studies, Vol. 19, No. 1 (Fall 2011), pp. 26-65; Mats Berdal, “The UN after Iraq," Survival, Vol. 46, No. 3, 2004, p. 83-101; Jane Boulden, Thomas G. Weiss, "Tactical Multilateralism: Coaxing America back to the UN, Survival, Vol. 46, No. 3, 2004, pp. 103-114.

19. Stockholm International Peace Research Institute..., op. cit., p. 182.

20. A 2005 Royal United Services Institute for Defence and Security Studies (RUSI) report for the Lounsbery Foundation (NATO Science and Technology, Trends, 
Challenges, and Priorities for Reform, November 2005), drew attention to the need for NATO to support scientific work in the "intellect-rich, budget-poor" nations of the alliance.

21. Bruce D. Porter, "The Warfare State," American Heritage, Vol. 45, No. 4 (July/August 1994), p. 52.

22. See Thomas E. Ricks, The Gamble: General David Petraeus \& the American Military Adventure in Iraq 2006-08, Penguin Press, 2009.

23. A 2005 Royal United Services Institute for Defence and Security Studies (RUSI) report for the Lounsbery Foundation (NATO Science and Technology, Trends, Challenges, and Priorities for Reform, November 2005), drew attention to the need for NATO to support scientific work in the "intellect-rich, budget-poor" nations of the alliance.

24. See Christopher Layne and Bradley Thayer, American Empire: A Debate (New York: Routledge, 2006); Niall Ferguson, Colossus: The Price of American Empire (New York: Penguin, 2004); Josef Joffe, Uberpower: The Imperial Temptation of America (New York: W.W. Norton, 2006), pp. 27-28; Daniel Nexon and Thomas Wright, "What's at Stake in the American Empire Debate," American Political Science Review, Vol. 101, No. 2 (May 2007), p. 253.

25. See Paul K. MacDonald and Joseph M. Parent, "Graceful Decline? The Surprising Success of Great Power Retrenchment," International Security, Vol. 35, No. 4 (Spring 2011), pp. 7-44; Christopher Layne, "The Waning of U.S. Hegemony-Myth or Reality? A Review Essay,” International Security, Vol. 34, No. 1 (Summer 2009), pp. $147-172$.

26. See DeborahWelch Larson and Alexei Shevchenko, "Status Seekers: Chinese and Russian Responses to U.S. Primacy," International Security, Vol. 34, No. 4 (Spring 2010), pp. 63-95.

27. Jason Lyall and Isaiah Wilson III, "Rage against the Machines: Explaining Outcomes in CounterinsurgencyWars," International Organization, Vol. 63, No. 1 (Winter 2009), pp. 67-106.

28. Reid Sarkees and Frank Wayma, Resort to War: A Data Guide to Inter-state, Extrastate, Intra-state, and Non-state Wars, 1816-2007 (Washington D.C.: CQ Press, 2010).

29. See Robert A. Pape, "Empire Falls," National Interest, No. 99 (January/February 2009), pp. 21-34; Stephen S. Cohen and J. Bradford DeLong, The End of Influence: What Happens When Other Countries Have the Money (New York: Basic Books, 2010).

30. See Jonathan D. Caverley, "Death and Taxes: Sources of Democratic Military Aggression," Ph.D. dissertation, University of Chicago, 337 pages.

31. 31See John J. Mearsheimer, The Tragedy of Great Power Politics (New York: W.W. Norton, 2001), p. 33-45.

32. Reid Sarkees and Frank Wayma, Resort to War: A Data..., op. cit., pp. 74-89.

33. See G. John Ikenberry, "Democracy, Institutions, and American Restraint," in Ikenberry, ed., America Unrivalled: The Future of the Balance of Power (Ithaca, N.Y.: Cornell University Press, 2002), pp. 207, 224-227.

34. See Thomas J. Christensen and Jack Snyder, "Chain Gangs and Passed Bucks: Predicting Alliance Patterns in Multipolarity," International Organization, Vol. 44, No. 2 (Spring 1990), pp. 137-168; Stephen M. Walt, The Origins of Alliances (Ithaca, N.Y.: Cornell University Press, 1987). 
35. See Jack Snyder, Robert Shapiro, and Yaeli Bloch-Elkon, "Free Hand Abroad, Divide and Rule at Home," World Politics, Vol. 61, No. 1 (January 2009), p. 155; Stephen M. Walt, "Alliances in a Unipolar World," World Politics, Vol. 61, No. 1 (January 2009), pp. 94-95.

36. See D. Scott Bennett and Allan C. Stam, "The Declining Advantages of Democracy: A Combined Model of War Outcomes and Duration," Journal of Conflict Resolution, Vol. 42, No. 3 (June 1998), pp. 344-366; Bruce Bueno de Mesquita, Alastair Smith, Randolph M. Siverson, and James D. Morrow, The Logic of Political Survival (Cambridge, Mass.: MIT Press, 2003); Darren Filson and Suzanne Werner, "Bargaining and Fighting: The Impact of Regime Type on War Onset, Duration, and Outcomes," American Journal of Political Science, Vol. 48, No. 2 (Fall 2004), pp. 296-313; Dan Reiter and Allan C. Stam, Democracies at War (Princeton, N.J.: Princeton University Press, 2002).

37. See John J. Mearsheimer, "Reckless States and Realism," International Relations, Vol. 23, No. 2 (June 2009), pp. 241-256.

38. See Christopher Layne, "The Unipolar Illusion Revisited: The Coming End of the United States' Unipolar Moment," International Security, Vol. 31, No. 2 (Fall 2006), pp. 61-83; John Ikenberry, Michael Mastanduno, and William C. Wohlforth, "Introduction: Unipolarity, State Behavior, and Systemic Consequences," World Politics, Vol. 61, No. 1 (January 2009), p. 25.

39. James Fearon, David Laitin, "Neotrusteeship and the problem of weak States," International Security, Vol. 28, No. 4, 2004, p. 5-43.

40. See I use Robert J. Art, A Grand Strategy for America (Ithaca, N.Y.: Cornell University Press, 2003), p. 2. See Robert J. Art, A Grand Strategy for America (Ithaca, N.Y.: Cornell University Press, 2003), p. 12; Barry Posen and Andrew L. Ross, "Competing Visions for U.S. Grand Strategy," International Security, Vol. 21, No. 3 (Winter 1996/97), pp. 5-53.

41. Bethany Encina and Nils Petter Gleditch, "Monitoring Trends in Global..., op. cit., p.33-46.

42. See, Headquarters Department of the Army Washington, DC, Counterinsurgency, Marine Corps Warfighting Publication, December 2006

43. See Boutros Boutros-Ghali, "An Agenda for Peace: Preventive Diplomacy, Peacemaking and Peacekeeping, 17 June, 1992. Available at: http://www.un.org/ Docs/SG/agpeace.html

44. See Gareth Evans, "When is it right to fight?", Survival, Vol. 46, No. 3, 2004, pp. 5982 .

45. See Brian URQUHART, "Security after the Cold War In: A. Roberts, B. Kingsbury (Ed.), United Nations, Divided World, Oxford: Oxford University Press, 2003.

46. See Peter Viggo JAKOBSEN, "The Transformation of United Nations Peace Operations in the 1990s: Globalization Adding to the Conventional "End of the Cold War Explanation," Cooperation and Conflict, Vol. 37, No. 3, 2002, p. 267-282; Thomas Weiss, David Forsythe, Roger Coate, The United Nations and Changing World Politics, Boulder: Westview Press, 2001.

47. See Peter Walleensteen, Patrik Johansson, "Security Council Decisions in Perspective, In: D. Malone (Ed.), The UN Security Council: From the Cold War to the 21st Century. Boulder: Lynne Rienner, 2004.

48. See Michael Barnette, "UN Security Council, Indifference, and Genocide in Rwanda," Cultural Anthropology, Vol. 12, No. 4, 1997, p. 551-578, 1997. 
49. See Christopher Layne, "The Unipolar Illusion: Why New Great Powers Will Rise," International Security, Vol. 17, No. 4 (Spring 1993), p. 5-19; Robert Kagan, The Return of History and the End of Dreams (New York: Alfred A. Knopf, 2008), p. 86; Stephen G. Brooks and William C. Wohlforth, World Out of Balance: International Relations and the Challenge of American Primacy (Princeton, N.J.: Princeton University Press, 2008); William C. Wohlforth, "The Stability of a Unipolar World," International Security, Vol. 24, No. 1 (Summer 1999), p. 8-36.

50. See Robert S. Ross and Zhu Feng, eds., China's Ascent: Power, Security, and the Future of International Politics (Ithaca, N.Y.: Cornell University Press, 2008); and Randall L. Schweller and Xiaoyu Pu, "After Unipolarity: China's Visions of International Order in an Era of U.S. Decline,” International Security, Vol. 36, No. 1 (Summer 2011), pp. 41-72.

\title{
Summary
}

\section{Modern Warfare and Its Evolving Weapons - Assumptions and Inherent Contradictions}

\section{Richard Rousseau}

\author{
Khazar University, Baku, Azerbaijan
}

The link between the world of 1906 and that of 2012 is diffuse and weak; it is more the product of chaos theory than a proverbial golden thread. So far in the 21 st century the world has been shocked and surprised by dramatic international events. There is little convincing evidence that this tendency to be shocked and surprised will not continue into the indefinite future. In today's world, the military focuses predominantly on land based irregular warfare, even if attacks can also come from the air and sea. However, despite the continued threat these pose, international air and sea trade transport continues, and is even increasing. Change in the defense and security fields is bound to occur because, around the world, countries' military and criminal organizations always want to improve their capability to do what they want to do. Powerful countries should not count on being liked and admired. They are more likely to be opposed and annoyed asymmetrically. This article is about the contrasts between 21 st century warfare and the forms we have previously witnessed. Highly developed societies will attempt to "engage the enemy more closely" from further away, the use of the Unmanned Aerial Vehicle (UAV) being the most prominent example.

Key words: Warfare, Weapons, Military, Insurgency, United-States, Change 